\title{
Measurement of Atmospheric Sulfuric Acid Particles Using Diazomethane Methylation
}

\author{
By Sachio Ohta \\ Department of Sanitary and Environmental Engineering, \\ Hokkaido University, Sapporo 060, Japan \\ Toshiichi Okita \\ National Institute for Environmental Studies, Tsukuba, Ibaraki 305, Japan \\ and \\ Fumihiro Kusaka \\ Shin-Nihon Kisho-Kaiyo Co., Ltd., Tamagawa, 3-14-5, Tokyo 158, Japan \\ (Received March 23, 1984; in revised form December 7, 1984)
}

\begin{abstract}
A method of measurement of atmospheric sulfuric acid particles was developed by modifying a method proposed by Penzhorn and Filby (1976). This method used an assembly for the generation of diazomethane and methylation of sulfuric acid. The minimum detection of $\mathrm{H}_{2} \mathrm{SO}_{4}$ was $3 \mathrm{ng}$. The amount of sulfuric acid particles generated in a test chamber determined by this method agreed well with those by barium chloranilate and titration methods. On field sampling gaseous $\mathrm{NH}_{3}$ which converted $\mathrm{H}_{2} \mathrm{SO}_{4}$ to $\left(\mathrm{NH}_{4}\right)_{2} \mathrm{SO}_{4}$ was eliminated by using an $\mathrm{NH}_{3}$ denuder.

In Tokyo, in August of 1981 the concentrations of sulfuric acid particles were $0.3 \cdots 4.7$ $\mu \mathrm{g} \mathrm{m}^{-3}$. In Sapporo they were $0.21 .3 \mu \mathrm{g} \mathrm{m}^{-3}$ between May and July in 1981, and 0.1-1.4 $\mu \mathrm{g} \mathrm{m}^{-3}$ between November in 1981 and January in 1982 respectively. 'The cumulative fraction by weight of sulfuric acid particles less than $2.1 \mu \mathrm{m}$ in diameter was $90 \%$. The ratio of $\mathrm{H}_{2} \mathrm{SO}_{4} / \mathrm{SO}_{4}^{2-}$ increased with decreasing particle diameter.
\end{abstract}

\section{Introduction}

Since atmospheric sulfuric acid particles are responsible for their effect on human health and acid rain, numerous methods have been developed for their determination such as barium chloride vapor-deposited thin film method, extraction into organic solvent, gas phase titration, infrared spectroscopy, acidbase indicator, sublimation, and titration. Of these methods, a vapor-deposited thin film method developed by Bigg et al. (1974) can determine individual sulfuric acid particles effectively. However, it requires much expertise and labor for its operation. Further, other methods have not been tested at length in the field. According to the evaluation by Appel et al. (1980), even with the popular extraction with benzaldehyde and titrimetry the recovery of sulfuric acid was not quantitative.

In this report, the methylation of $\mathrm{H}_{2} \mathrm{SO}_{4}$ by means of diazomethane proposed by Penzhorn and Filby (1976) is modified to be applicable to the field measurement of sulfuric acid particles.

\section{Diazomethane method}

Penzhorn and Filby (1976) washed off $\mathrm{H}_{2} \mathrm{SO}_{4}$ with ether solution of diazomethane from an 


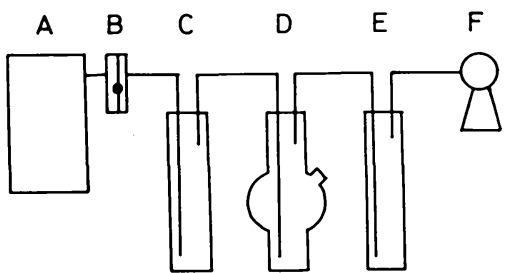

Fig. 1 An assembly for the generation of diazomethane and methylation of sulfuric acid.
A : Teflon bag
B : Rotameter
$C$ : Impinger
D: Bubbler
$\mathrm{E}$ : Impinger
F : Pump

aerosol collection filter, and dimethyl sulfuric acid thus produced was detected by FPD-GC. However, since diazomethane is noxious and explosive, the following simple procedure is adopted in the present study. Figure 1 shows an assembly for the generation of diazomethane and methylation of sulfuric acid. An impinger $\mathrm{C}$ contains $10 \mathrm{ml}$ of ether, a bubbler $\mathrm{D}$ contains a mixture of $10 \mathrm{~m} l$ of diethylene glycol and 1 to $2 \mathrm{ml}$ of water which dissolves 5 to 6 pellets of potassium hydroxide, and an impinger $\mathrm{E}$ contains $10 \mathrm{ml}$ of ether and a filter on which $\mathrm{H}_{2} \mathrm{SO}_{4}$ particles are collected.

On introducing $\mathrm{N}_{2}$ gas with a flow rate of 20 to $40 \mathrm{ml} \mathrm{min}^{-1}$ through the assembly while $5 \mathrm{~m} l$ of $1 \%(\mathrm{w} / \mathrm{w})$ acetone solution of $\mathrm{N}$ methyl-N-nitro-N-nitroso guanidine (MNNG) is placed into $\mathrm{D}$, the diazomethane gas is immediately liberated and methylation is conducted in E. At equivalence point color of the ether solution in $\mathrm{E}$ turns yellow. When no yellow color does not develop even at 10 minutes after the addition of MNNG, further MNNG solution is added into D. Diethyl sulfuric acid is added to the methylated solution in $\mathrm{E}$ as an internal standard, and then the solution is concentrated to $100 \mu l$ on a water bath at $40^{\circ} \mathrm{C}$. The concentrated solution is subjected to flame-photometric gas chromatographic analysis.

Table 1 shows the operating condition of the flame-photometric gas-chromatograph (FPD-GC), and Fig. 2 shows a calibration curve for dimethyl sulfuric acid.

For the calibration $0.5-2 \mu l$ of $2-10000 \mathrm{ppm}$ ether solution of dimethyl sulfuric acid was injected into FPD-GC by means of a micro-
Table 1 Operating condition of gas chromatograph.

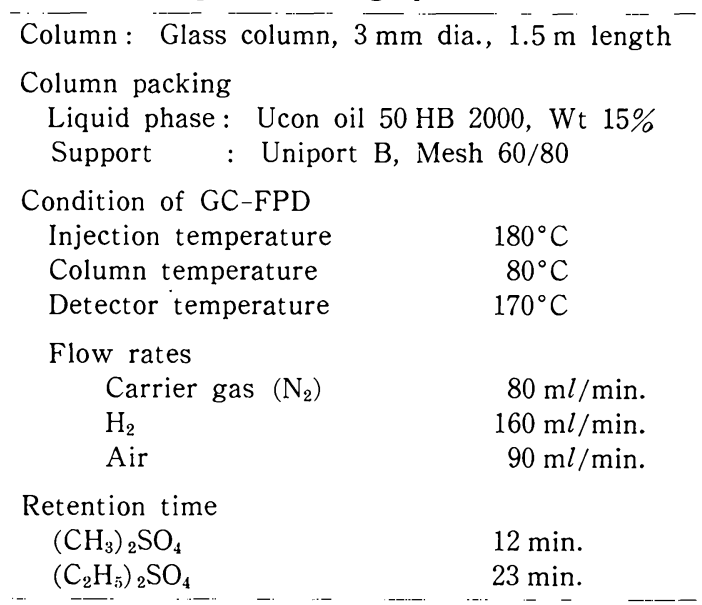

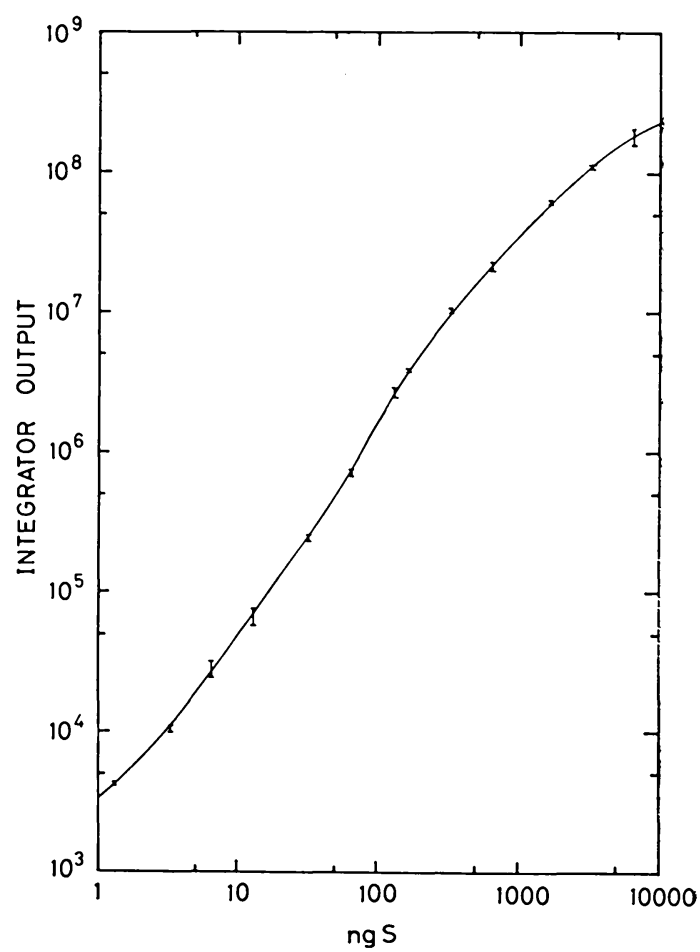

Fig. 2 Calibration curves for dimethyl sulfuric acid $\left(\left(\mathrm{CH}_{3}\right)_{2} \mathrm{SO}_{4}\right)$ (Abscissa is amount of $\left(\mathrm{CH}_{3}\right)_{2} \mathrm{SO}_{4}$ in $\left.\mathrm{ngS}\right)$.

syringe. The amount of sulfur contained in each injection was ranged from 1.3 to $6520 \mathrm{ng}$ at 13 different levels. At each level three to five samples were taken.

The detection limit of $\mathrm{H}_{2} \mathrm{SO}_{4}$ was $3 \mathrm{ng}$. Then if the $\mathrm{H}_{2} \mathrm{SO}_{4}$ particles are sampled on a filter for 3 hours at flow rate of $20 l \mathrm{~min}^{-1}$, 


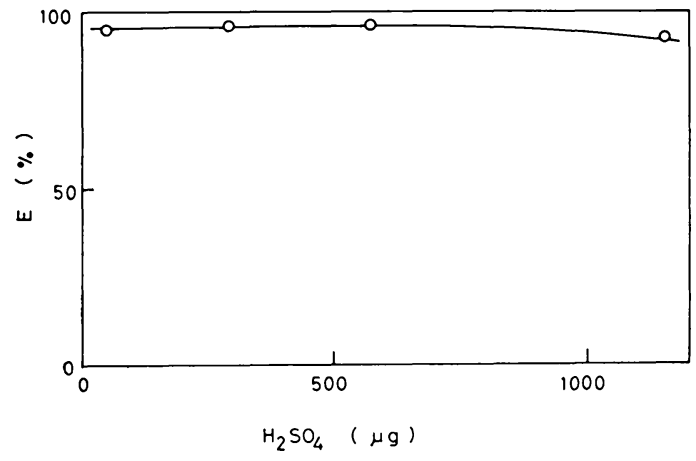

Fig. 3 Methylation efficiency (E).

the extract of the sampled filter is concentrated to $100 \mu l$, and $5 \mu l$ of the concentrated solution is injected into the gas chromatograph, the minimum measurable concentration of $\mathrm{H}_{2} \mathrm{SO}_{4}$ particles in the air is $0.02 \mu \mathrm{g} \mathrm{m}^{-3}$.

1 to $10 \mu$ of $\mathrm{H}_{2} \mathrm{SO}_{4}$ solution of 3.6 to $18 \mathrm{~N}$ in concentration is soaked to a quartz fiber filter and methylation is conducted. As shown in Fig. 3, with $\mathrm{H}_{2} \mathrm{SO}_{4}$ amount of less than $500 \mu \mathrm{g}$ methylation efficiency is greater than $95 \%$. If the sample contains moisture or methanol, the reactions

$$
\begin{aligned}
& \left(\mathrm{CH}_{3}\right)_{2} \mathrm{SO}_{4}-\mathrm{H}_{2} \mathrm{O} \longrightarrow \mathrm{CH}_{3} \mathrm{OH}+\mathrm{CH}_{3} \mathrm{HSO}_{4} \\
& \left(\mathrm{CH}_{3}\right)_{2} \mathrm{SO}_{4}+\mathrm{CH}_{3} \mathrm{OH} \rightarrow \cdots\left(\mathrm{CH}_{3}\right)_{2} \mathrm{O}+\mathrm{CH}_{3} \mathrm{HSO}_{4}
\end{aligned}
$$

gives negative interference, so that it is necessary for the sample to be dessipated before the methylation.

The ambient air is sampled on two quartz fiber filters of $4.7 \mathrm{~cm}$ in diameter simultaneously and $\mathrm{H}_{2} \mathrm{SO}_{4}$ in the aerosol is determined by the methylation technique as shown in Table 2. The concentrations of $\mathrm{H}_{2} \mathrm{SO}_{4}$ aerosols in I and II series in Table 2 indicate that the difference of the simultaneous measurements is within $10 \%$. In the field measure-

Table 2 Comparison of two parallel measurements of $\mathrm{H}_{2} \mathrm{SO}_{4}$ particles (Flow rate $20 l \mathrm{~min}^{-1}$, Sampling time 3 hours)

\begin{tabular}{c|cc}
\hline \multirow{2}{*}{ Run No. } & \multicolumn{2}{|c}{$\mathrm{H}_{2} \mathrm{SO}_{4}\left(\mu \mathrm{g} \mathrm{m}^{-3}\right)$} \\
& I & II \\
\hline 1 & 0.52 & 0.54 \\
2 & 0.81 & 0.91 \\
3 & 0.80 & 0.88 \\
\hline
\end{tabular}

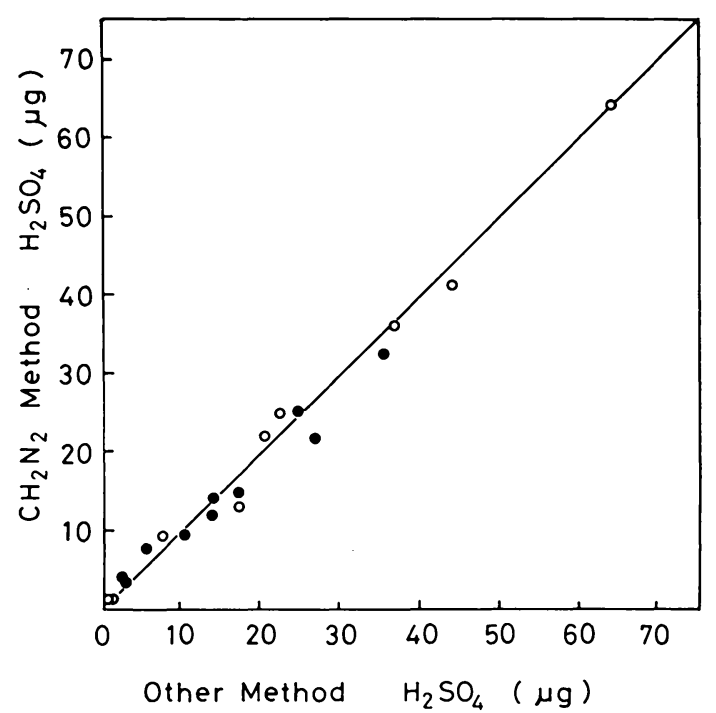

Fig. 4 Comparison of diazomethane method with barium chloranilate method $(\bigcirc)$ and titration method (-) for sulfuric acid particles generated in a test chamber.

ment, just after sampling, each aerosol collected quartz fiber filter is packed in a plastic case of $5 \mathrm{~cm}$ in diameter and $0.5 \mathrm{~cm}$ in thickness, and dessicated before the methylation.

\section{Comparison of diazomethane method with barium chloranilate and titration methods}

Sulfuric acid aerosol generated by using an atomizer in an acrylate chamber $700 l$ in volume is simultaneously sampled on two or three quartz fiber filters and determined by diazomethane method for $\mathrm{H}_{2} \mathrm{SO}_{4}$, barium chloranilate method for $\mathrm{SO}_{4}^{2-}$, and titration method for $\mathrm{H}_{2} \mathrm{SO}_{4}$ (Gran, 1952). Figure 4 indicates the close agreement of the amounts obtained by the three methods.

\section{Interferences}

(1) Dimethyl sulfate $\left(\left(\mathrm{CH}_{3}\right)_{2} \mathrm{SO}_{4}\right)$

Lee et al. (1980) found that the amounts of $\left(\mathrm{CH}_{3}\right)_{2} \mathrm{SO}_{4}$ on fly ash and coal ash are 100 and $10-40 \mu \mathrm{g} \mathrm{g}^{-1}$ respectively. According to our measurement they are $7 \mu \mathrm{g} \mathrm{g}^{-1}$ for coal ash, $300 \mu \mathrm{g} \mathrm{g}^{-1}$ for coal soot and $8000 \mu \mathrm{g} \mathrm{g}^{-1}$ for oil ash. Therefore, usually the presence of $\left(\mathrm{CH}_{3}\right)_{2} \mathrm{SO}_{4}$ does not interfere $\mathrm{H}_{2} \mathrm{SO}_{4}$ measurement. The three day air sampling on the campus of Hokkaido University did not detect 
$\left(\mathrm{CH}_{3}\right)_{2} \mathrm{SO}_{4}$.

(2) $\mathrm{NH}_{3}$

Since atmospheric $\mathrm{NH}_{3}$ would react with $\mathrm{H}_{2} \mathrm{SO}_{4}$ particles to produce $\left(\mathrm{NH}_{4}\right)_{2} \mathrm{SO}_{4}$, the $\mathrm{NH}_{3}$ denuder developed by Hara et al. (1982) was attached to the air inlet of the particle collection filter.

\section{(3) $\left(\mathrm{NH}_{4}\right)_{2} \mathrm{SO}_{4}$ and $\mathrm{NH}_{4} \mathrm{HSO}_{4}$}

Aqueous solution with proper concentration of $\left(\mathrm{NH}_{4}\right)_{2} \mathrm{SO}_{4}$ or $\mathrm{NH}_{4} \mathrm{HSO}_{4}$ is dropped onto a quartz fiber filter with a microsyringe. The filter is dried in a dessicator and the sample is analyzed by the diazomethane method.

No interference of $\left(\mathrm{NH}_{4}\right)_{2} \mathrm{SO}_{4}$ was found in the $\mathrm{H}_{2} \mathrm{SO}_{4}$ measurement, but methylation of $\mathrm{NH}_{4} \mathrm{HSO}_{4}$ produced $\left(\mathrm{CH}_{3}\right)_{2} \mathrm{SO}_{4}$ with an efficiency $85-95 \%$. Therefore, the $\mathrm{H}_{2} \mathrm{SO}_{4}$ and $\mathrm{NH}_{4} \mathrm{HSO}_{4}$ particles are defined as $\mathrm{H}_{2} \mathrm{SO}_{4}$ particles in the following sections.

\section{Size distribution of $\mathrm{H}_{2} \mathrm{SO}_{4}$ particles}

A combination of an Andersen sampler (Kanomax Inc. Model 5600) and a diffusion battery is used for the measurement of size distribution of $\mathrm{H}_{2} \mathrm{SO}_{4}$ particles. The diffusion battery is of plate type and its structure and operating condition are as follows. Length: $56 \mathrm{~cm}$, width: $20 \mathrm{~cm}$, spacing between plates: $1 \mathrm{~mm}$, channel numbers : 20 , and total air flow rate : $20 l \mathrm{~min}^{-1}$. The theoretical efficiency of particle penetration had been obtained by De-Marcus and Thomas (1952), to agree well with the experimental one measured by using an electrical aerosol analyzer. The diameter of $50 \%$ particle penetration is found to be $0.02 \mu \mathrm{m}$.

\section{Results and Discussion}

During August 4 to 13 in 1981 aerosol sampling was made on a roof of a six-story building of the National Institute of Public Health (IPH) located in the downtown of Tokyo. Figure 5 shows the concentration of atmospheric $\mathrm{H}_{2} \mathrm{SO}_{4}$ particles. High concentrations of $4.7 \mu \mathrm{gm}^{-3}, 3.9 \mu \mathrm{gm}^{-3}$ and $3.0 \mu \mathrm{gm}^{-3}$ were measured in the daytime of August 9, 10 and 12 respectively. During the sampling period temperature, relative humidity, and wind velocity were $24-28^{\circ} \mathrm{C}, 50-78 \%$, and

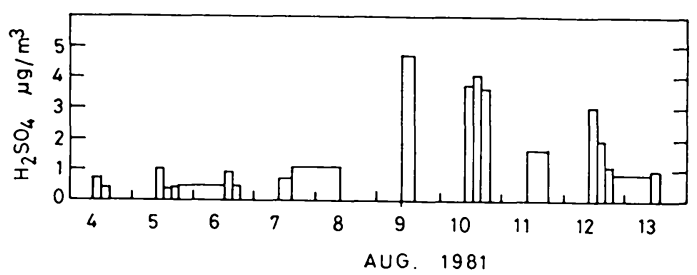

Fig. 5 Concentration of atmospheric sulfuric acid particles in Tokyo in August, 1981.

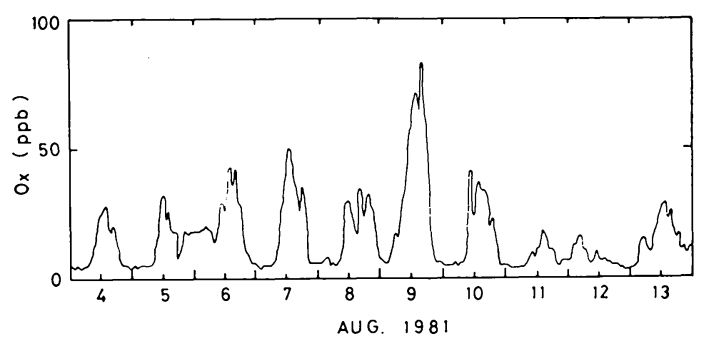

Fig. 6 Concentration of atmospheric oxidant at the Minato-ku air pollution observation station in Tokyo in August, 1981.

$1.5-5.0 \mathrm{~m} \mathrm{sec}^{-1}$, respectively. Figure 6 shows the concentration of atmospheric oxidants measured at the Minato-ku air pollution observation station near IPH. On August 9 the oxidant concentration rose to $70-83 \mathrm{ppbv}$ in the afternoon.

Therefore, high concentration of $\mathrm{H}_{2} \mathrm{SO}_{4}$ particles on August 9 seemed to be due to the photochemical conversion from $\mathrm{SO}_{2}$ in the atmosphere. On the other hand, oxidant concentration on August 10 was not so high, and on August 12 it was the lowest in the period, so that it seems that high concentrations of $\mathrm{H}_{2} \mathrm{SO}_{4}$ particles on these days were not due to photochemical production. Besides photochemical production, $\mathrm{H}_{2} \mathrm{SO}_{4}$ particles are also emitted directly in the air from diesel exhaust and heavy oil combustion furnace. On August 10 and 12 the wind directions were SW and $\mathrm{SE}$, respectively, and wind speed was $2 \mathrm{~m}$ $\mathrm{sec}^{-1}$. As there are heavy industrial areas in the southwest and southeast of Tokyo known as Keihin and Keiyo industrial areas, respectively, high concentration of $\mathrm{H}_{2} \mathrm{SO}_{4}$ on these days seemed to be due to the advection of $\mathrm{H}_{2} \mathrm{SO}_{4}$ particles emitted primarily by industrial activity in those areas.

Aerosol sampling was also made in Sapporo on a roof of our laboratory building, which is 
Table 3. Concentration of atmospheric sulfuric acid particles in Sapporo from May to July, 1981.

\begin{tabular}{|c|c|c|}
\hline Date & Time & $\mathrm{H}_{2} \mathrm{SO}_{4}\left(\mu \mathrm{g} \mathrm{m}^{-3}\right)$ \\
\hline May 1 & $14: 30-17: 00$ & 1.3 \\
\hline \multirow[t]{2}{*}{ May 2} & $11: 00-14: 00$ & 0.9 \\
\hline & $14: 00-17: 00$ & 0.9 \\
\hline May 4 & $14: 00-17: 00$ & 1.0 \\
\hline Jun. 8 & $5: 30-12: 00$ & 1.1 \\
\hline Jun. 22 & $12: 00-20: 15$ & 0.5 \\
\hline Jun. 23 & $12: 30-20: 30$ & 0.9 \\
\hline Jul. 3 & $8: 15-20: 15$ & 0.3 \\
\hline Jul. 4 & $8: 20-20: 00$ & 0.5 \\
\hline Jul. 7 & $9: 00-21: 30$ & 0.7 \\
\hline Jul. $\quad 9$ & $10: 30-17: 30$ & 0.3 \\
\hline Jul. 10 & $12: 45-20: 30$ & 0.2 \\
\hline
\end{tabular}

$26 \mathrm{~m}$ above the ground, in the university campus from May to July in 1981 and from November in 1981 to January in 1982. The concentration of $\mathrm{H}_{2} \mathrm{SO}_{4}$ particles in summer (May-July) shown in Table 3 ranged from 0.2 to $1.3 \mu \mathrm{g} \mathrm{m}^{-3}$. Temperature and relative humidity during the sampling were 10.7$20.5^{\circ} \mathrm{C}$ and $54-90 \%$ respectively. High concentrations of $\mathrm{H}_{2} \mathrm{SO}_{4}$ particles as observed May 1, May 4 and June 8 were not correlated with high temperature and relative humidity.
The arithmetric mean concentration of $\mathrm{H}_{2} \mathrm{SO}_{4}$ particles was $0.7 \mu \mathrm{g} \mathrm{m}^{-3}$.

The $\mathrm{H}_{2} \mathrm{SO}_{4}$ concentration in winter (Nov., 1981-Jan., 1982) in Sapporo is shown in Fig. 7 , which also shows the concentrations of sulfate, nitrate, chloride, ammonium, and their ionic balance $\left(\left[\mathrm{H}^{+}\right]+\left[\mathrm{NH}_{4}^{+}\right]-2\left[\mathrm{SO}_{4}^{2-}\right]-\left[\mathrm{NO}_{3}^{-}\right]\right.$ $\left.-\left[\mathrm{Cl}^{-}\right]\right)$. The concentration of $\mathrm{H}_{2} \mathrm{SO}_{4}$ particles ranged from 0.1 to $1.4 \mu \mathrm{g} \mathrm{m}^{-3}$, and its arithmetic mean was $0.5 \mu \mathrm{g} \mathrm{m}^{-3}$, which was a little lower than that in summer. Sulfuric acid was comprised of sulfate by about $20 \%$ in mass. The temperature and relative humidity during the measurement were $-5 \sim 7^{\circ} \mathrm{C}$ and $50-90 \%$ respectively, and high concentration of $\mathrm{H}_{2} \mathrm{SO}_{4}$ particles did not correlate with high temperature and humidity. The negative deviation from the ionic balance was observed in most cases, which suggested the presence of other cations such as $\mathrm{Na}^{+}$and $\mathrm{Ca}^{2+}$. On the other hand, the positive deviation, which presupposed the presence $\mathrm{NH}_{4} \mathrm{HSO}_{4}$, was seldom observed.

Size distributions of $\mathrm{H}_{2} \mathrm{SO}_{4}$ and sulfate particles were measured in Sapporo from Dec. 21 to 29,1981 and from Jan. 16 to 23,1982 . As the distribution pattern in the two cases were similar, only the former is shown in Figs. 8 and $9 . \mathrm{H}_{2} \mathrm{SO}_{4}$ particles (Fig. 8) had the highest

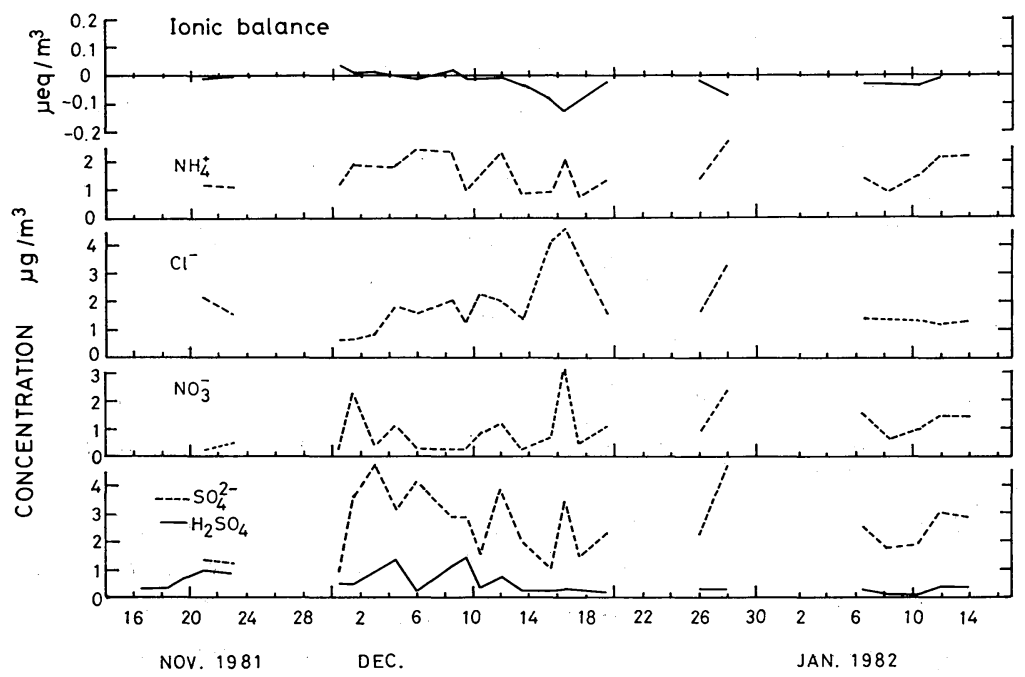

Fig. 7 Concentrations of atmospheric sulfuric acid particles $\left(\mathrm{H}_{2} \mathrm{SO}_{4}\right)$, sulfate $\left(\mathrm{SO}_{4}^{2-}\right)$, nitrate $\left(\mathrm{NO}_{3}^{-}\right)$, chloride $\left(\mathrm{Cl}^{-}\right)$, ammonium $\left(\mathrm{NH}_{4}^{+}\right)$and their ionic balance $\left(\left[\mathrm{H}^{+}\right]+\left[\mathrm{NH}_{4}^{+}\right]-2\left[\mathrm{SO}_{4}^{2-}\right]-\left[\mathrm{NO}_{3}^{-}\right]-\left[\mathrm{Cl}^{-}\right]\right)$in Sapporo from November, 1981 to January, 1982. 


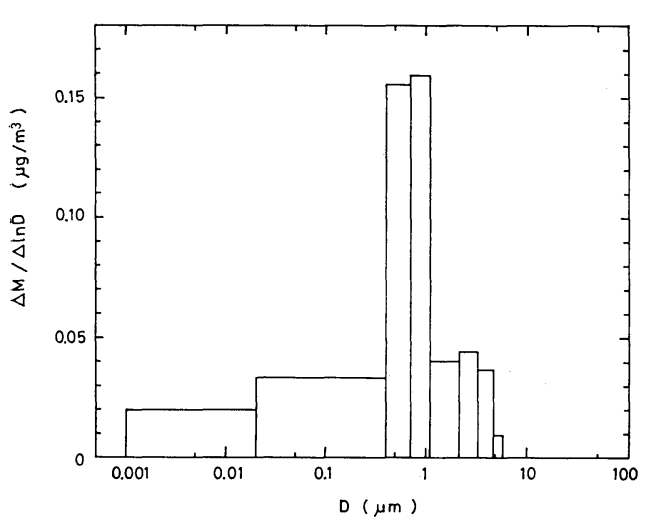

Fig. 8 Size distribution of atmospheric sulfuric acid particles in Sapporo. Sampling period was from December 21 to 29, 1981. M denotes the concentration of sulfuric acid particles $\left(\mu \mathrm{g} \mathrm{m}^{-3}\right)$ and $\mathrm{D}$ is the diameter of the particles.

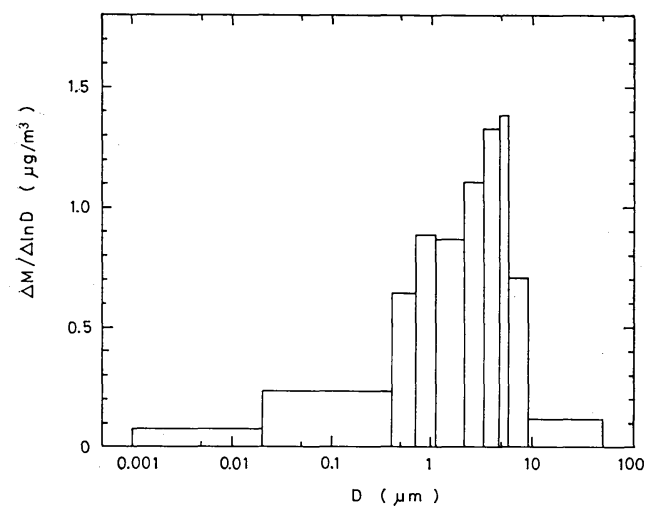

Fig. 9 As in Fig. 8 but for sulfate.

peak between 0.7 and $1.1 \mu \mathrm{m}$ in diameter, whereas sulfate particles (Fig. 9) had the peak between 4.7 and $5.8 \mu \mathrm{m}$. Cumulative fractions by weight of $\mathrm{H}_{2} \mathrm{SO}_{4}$ and sulfate particles less than $2.1 \mu \mathrm{m}$ in diameter were 90 and $60 \%$ respectively. This means that most $\mathrm{H}_{2} \mathrm{SO}_{4}$ particles were contained in the fine particle regime less than $2 \mu \mathrm{m}$ in diameter. Generally it is thought that the fine particles are generated from combustion or formed by atmospheric reaction. Since in this period no photochemical reaction seemed to occur, it is presumed that $\mathrm{H}_{2} \mathrm{SO}_{4}$ particles were directly discharged from combustion sources. In the atmosphere, water-soluble inorganic particles less than $2 \mu \mathrm{m}$ in diameter may be composed of $\left(\mathrm{NH}_{4}\right)_{2} \mathrm{SO}_{4}, \mathrm{NH}_{4} \mathrm{HSO}_{4}, \mathrm{NH}_{4} \mathrm{NO}_{3}$ and $\mathrm{NH}_{4} \mathrm{Cl}$ as well as $\mathrm{H}_{2} \mathrm{SO}_{4}$ because they are produced

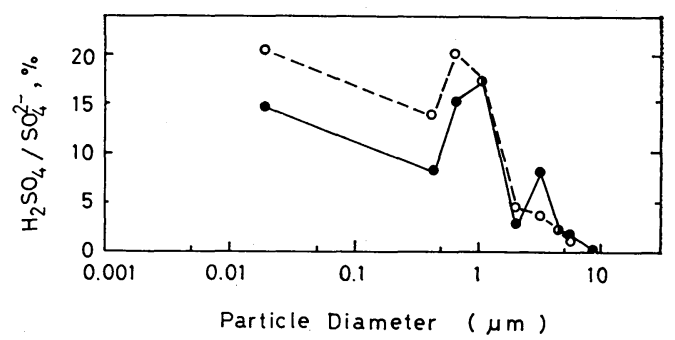

Fig. 10 Variation of the ratio of $\mathrm{H}_{2} \mathrm{SO}_{4} / \mathrm{SO}_{4}^{2-}$ with particle diameter.

$O$ : Sampling period was from Dec. 21 to 29 , 1981.

- : Sampling period was from Jan. 16 to 23 , 1982.

in the combustion furnace or in the atmosphere (Whitby, 1978). If this is true, then by collecting the particles less than $2 \mu \mathrm{m}$ in diameter by means of a cascade impactor and by analyzing the amount of $\mathrm{H}_{2} \mathrm{SO}_{4}, \mathrm{SO}_{4}^{2-}, \mathrm{NH}_{4}^{+}$, $\mathrm{NO}_{3}^{-}$and $\mathrm{Cl}^{-}$, we can estimate the amount of $\mathrm{NH}_{4} \mathrm{HSO}_{4}$ from the difference of these ionic balance $\left(\left[\mathrm{H}^{+}\right]+\left[\mathrm{NH}_{4}^{+}\right]-2\left[\mathrm{SO}_{4}^{2-}\right]-\left[\mathrm{NO}_{3}^{-}\right]-\right.$ $\left.\left[\mathrm{Cl}^{-}\right]\right)$in which $\left[\mathrm{H}^{+}\right]$is determined from the amount of $\mathrm{H}_{2} \mathrm{SO}_{4}$ measured by the diazomethane method.

Figure 10 shows the variation of the ratio of $\mathrm{H}_{2} \mathrm{SO}_{4} / \mathrm{SO}_{4}^{2-}$ with particle diameter in the two measurements. The ratio increased with decreasing particle diameter, although it had a dip at $0.5 \mu \mathrm{m}$.

In conclusion, by using the present method, atmospheric sulfuric acid particles can easily be measured. However, as the method cannot distinguish $\mathrm{NH}_{4} \mathrm{HSO}_{4}$ from $\mathrm{H}_{2} \mathrm{SO}_{4}$, we may overestimate the amount of $\mathrm{H}_{2} \mathrm{SO}_{4}$ particles in the field.

\section{References}

Appel, B. R., S. M. Wall, M. Haik, E.L. Kothny and Y. Tokiwa, 1980: Evaluation of techniques for sulfuric acid and particulate strong acidity measurements in ambient air. Atmos. Environ., 14, 559-563.

Bigg, E. K., A. Ono and J. Williams, 1974 : Chemical tests for individual submicron aerosol particles. Atmos. Environ., 8, 1-13.

De-Marcus, W. and J.W. Thomas, 1952: Theory of a Diffusion Battery. USAEC Report ORNL1413, Oak Ridge National Laboratory, Oct. 16.

Gran, G., 1952: Determination of the equivalence point in potentiometric titrations. Analyst, 77, 661-671. 
Hara, H., M. Kurita and T. Okita, 1982: Ammonia denuder for field sampling of sulfuric acid particles. Atmos. Environ., 16, 1565-1566.

Lee, M. L., D. W. Later, D. K. Rollins, D. J. Eatough and L.D. Hanson, 1980: Dimethyl and monomethyl sulfate: Pressence in coal fly ash and airborne particulate matter. Science, 207, 186-
188.

Penzhorn, R. D. and W. G. Filby, 1976: Eine Methode zur spezifischen Bestimmung von schwefelhaltigen Säuren im atmosphärischen Aerosol. Staub-Reinhalt. Luft., 36, 205-207.

Whitby, K.T., 1978: The physical characteristics of sulfur aerosols. Atmos. Environ., 12, 135-159.

\title{
ジアゾメタンによるメチル化法を用いた大気中の硫酸粒子の測定
}

\author{
太田幸 雄 \\ 北海道大学工学部衛生.T.学科 \\ 大喜多 敏 一 \\ 国立公害研究所 \\ 日下文博 \\ 新日本気象海洋株式会社
}

\begin{abstract}
大気中の硫酸粒子の測定法について Penzhorn と Filby（1976）によって行われた方法を改良した新しい測 定法を考案した。この新測定法では, ジアゾメタンを発生させて直接硫酸をメチル化する装置を用いている。 硫酸の検出限界は $3 \mathrm{ng}$ である。テストチャンバー内に発生させた硫酸粒子について，本方法とクロラニル酸 バリウム法及び滴定法とで測定を行ったところ，良く一致した。野外測定において硫酸を硫酸アンモニウムに 変換してしまうために問題となるアンモニアガスは，アンモニア除去管を用いることにより除去した。

1981年の 8 月の東京における大気中の硫酸粒子の濃度は 0.3 4.7 $\mathrm{g} \mathrm{m}^{-3}$ であった。札幌に拈いては，硫酸 粒子濃度は, 1981 年の 5 月〜 7 月は $0.2 \sim 1.3 \mu \mathrm{g} \mathrm{m}^{-3}, 1981$ 年 11 月〜 1982年 1 月は $0.1 \sim 1.4 \mu \mathrm{g} \mathrm{m}^{-3}$ であっ た。直径 $2.1 \mu \mathrm{m}$ 以下の硫酸粒子の重量累積頻度は $90 \%$ であった。硫酸 $\left(\mathrm{H}_{2} \mathrm{SO}_{4}\right)$ と硫酸塩 $\left(\mathrm{SO}_{4}^{2-}\right)$ の比は, 粒径が減少するに従い増加した。
\end{abstract}

